\title{
Implementation of One-Stop Services Policy In North Jakarta City, Jakarta Province
}

\author{
Mary Ismowati ${ }^{1}$, Akhmad Hidayat Rahadian², Muhammad Ali Massyhury ${ }^{3}$, \\ and Muhammad Rafi Suryadi ${ }^{4}$ \\ ${ }^{1}$ Lecturer at the Graduate Program at the Stiami Institute of Social Sciences and Management \\ Email : maryismowati1967@gmail.com ${ }^{1}$ \\ Email : rahadian.ah@gmail.com² \\ Email : alinzgtl@gmail.com ${ }^{3}$ \\ Email : muhammadrafisuryadi62@gmail.com ${ }^{4}$
}

(Received: August 10-2020; revised: October 28-2020; published: December 31-2020)

\begin{abstract}
The aim of the study was to obtain a formulation of the implementation of the One-Stop Services Policy (PTSP) in the North Jakarta Administrative City, namely the implementation of Perda No. 12 of 2013, and the Implementation of Presidential Regulation No. 91 of 2017 concerning the acceleration of ease of doing business through the implementation of an information technology-based licensing system (OSS). The research method used a qualitative approach by conducting interviews with a number of informants to determine the conditions and phenomena of the implementation of PTSP policies in North Jakarta. The research involved two research members from students in the framework of thesis research. The results of the research show that implementers have understood their duties and functions, but in the smooth running of their duties, they are constrained by a lack of human resources both in quantity and quality, support for information technology equipment that is not up to date, including the availability of information technology personnel at the district and sub-district levels. Then the OSS policy according to PP No. 24/2018 has not been fully effective, because it has not been fully integrated with the existing licensing system in PM-PTSP DKI Jakarta, namely JakEVO. The main obstacle to policy implementation, namely in terms of human resources, employee status has not been transferred to functional positions so that it affects career ranks and motivation. In addition, there is no HR competency standard for services, for online system services are not implemented according to target. The solution to overcome the obstacles conceptually has not been done.
\end{abstract}

Keywords: Policy implementation, service quality, one-stop integrated service, Online Single Submission

\section{INTRODUCTION}

Through the Minister of Home Affairs Regulation No. 4 of 2010 stipulated integrated administrative service guidelines, hereinafter known as One-Stop Services (PTSP).

According to Oates (1995), the implementation of public services will be more efficient if they are carried out by a jurisdiction that has control over a certain geographic area so as to allow the optimization of benefits and costs. Therefore, one of the more effective ways to narrow the 


\section{2 | Jurnal Ilmiah Ilmu Administrasi Publik: Jurnal Pemikiran dan Penelitian Administrasi Publik \\ Volume 1o Number 2, July-December 2020. Page 381-388}

distance between service providers and service recipients is to decentralize public services (public services decentralization) through international decentralization with the aim of empowering front line staff (Pollitt, Birchall, and Putman, 1998: 5-13).

One of the government entities that provide services directly or indirectly to the community is the district and sub-district. As a sub-system of government in Indonesia, districts have a strategic position and play a functional role in the practice of government services and administration, development, and society (Wasistiono, Nurdin, and Fahrurozi, 2009: 200). In other words, the District is the spearhead and barometer of public service delivery, as well as a showcase for local government administration.

One-Stop Integrated Service (PTSP) in DKI Jakarta is stipulated through the DKI Jakarta Provincial Regulation No. 12/2013 carried out from the Provincial, City / Regency, District, and sub-district levels. So that the number of PTSP includes 318 service points located in $247 \mathrm{Sub}-$ district, 44 District, 6 Regency / City and Province 1. In its development, there has been a change in the PTSP management institution, namely through the Regulation of the Governor of the Jakarta Capital City No.281 in 2016 "One-Stop Services (OSS) and Investment Service". In this change, an organizational structure was formed at the provincial level, namely the PTSP Implementing Unit at the City / Regency level, at the District Implementing Unit level and at the sub-district PTSP Implementing Unit level.

The research involved research members from students who carried out thesis research. The specific purpose and urgency of the research are to obtain a formulation for the implementation of the One-Stop Integrated Service Policy (PTSP) in DKI Jakarta Province. In particular regarding the policy of Perda no. 12 of 2013 and a series of Governor Regulations which are its derivatives, then the implementation of the SOP of PTSP and the implementation of the Presidential Regulation No. 91 of 2017 concerning the acceleration of ease of doing business through the implementation of an information technology-based licensing system or Online Single Submission (OSS).

From the results of observations, the implementation of PM-PTSP policies in the North Jakarta Implementing Unit, it is known: The level of implementor compliance has not yet met expectations, this is indicated by the implementation of the technical assessment process on licensing services that still depend on other agencies, not carried out independently; The quality of service is not as expected, this is indicated by the discovery of several complaints from the public regarding the service process; Service routines still face obstacles in the form of network constraints for online service needs caused by limited bandwidth, less large servers, and less fast network connections; and previous year's performance achievements (2019) have not reached the targets set in the Performance Plan.

The results of research by the Regional Autonomy Monitoring Committee (KPPOD) in 2019 (Bisnis.com: 2019), assess that there are still many local governments who view the existence of Online Single Submission (OSS) as a form of decentralization of licensing authority. namely regulations, systems, and governance," 
Regulatory aspects at the center, Norms, Standards, Procedures, and Criteria or sectoral NSPK which ideally serve as technical guidelines for permit services, so that they do not clearly translate Government Regulation (PP) Number 24 of 2018 concerning OSS into procedures that are easy to follow for all regions.

Apart from the NSPK, OSS mistakes are also reflected in the disharmony problem of PP 24 of 2018 with Law Number 15 of 2017 concerning Investment and Law Number 23 of 2014 concerning local government.

"Disharmony regarding the authority to give permits that previously was in the hands of the regional head has now moved to the OSS institution. The function of the licensing agency that was previously delegated by the Investment Law to PTSP has now shifted to the OSS institution,"

Another weakness of the OSS system is the feature of determining business locations that are not in sync with the Regional Spatial Plan (RTRW), as well as the availability of a Detailed Spatial Plan (RDTR).

"This could have implications for the establishment of business locations that are not in accordance with regional planning as stipulated in the RTRW document, or even not locationbased due to the absence of RDTR,"

In the aspect of governance, OSS also still faces obstacles, both at the central and regional levels. At the central level, the OSS system is not yet fully integrated with the Ministry / Agency licensing system. Meanwhile, in the regions, there are still many local governments that have application-based independent regional licensing systems (through PTSP) that are not yet integrated with OSS institutions. Even in major business areas such as DKI Jakarta, only integrating JakEVO and OSS is only in SIUP (trading bussines) licensing services. Other licenses are still being served in the DKI Jakarta independent system, "

Policies that occur in DKI Jakarta, including in the PM-PTSP implementation unit of North Jakarta, at the Provincial, City, and District levels, apply the online service policy through JakEVO. Meanwhile, OSS is only enforced in PM-PTSP implementing units. This policy was only stipulated verbally by the Head of the PM-PTSP Service at a meeting on January 5, 2020.

\section{METHOD}

The research method used is qualitative research, Creswell (2016: 4) defines "Qualitative Research is methods to explore and understand the meaning that a number of individuals or groups of people perceive from social or humanitarian problems: This qualitative research uses in-depth interview techniques, which was started by Dun, a respondent or a group of respondents, communicating materials and encouraging free discussion and interviewers are often trained to be able to explore hidden feelings and attitudes from respondents (Ardianto, 2014: 61). In-depth interviews emphasize several individual experiences that present data in the form of words and activities that focus on the process of understanding how a phenomenon arises and finding solutions to solving problems, but qualitative research can present data in the form of numbers if certain conditions are needed. 


\section{4 | Jurnal Ilmiah Ilmu Administrasi Publik: Jurnal Pemikiran dan Penelitian Administrasi Publik \\ Volume 10 Number 2, July-December 2020. Page 381-388}

The informants in the study consisted of seven employees, namely five at the North Jakarta Administrative City and two at the district level, while the service users were seven people, namely three at the district level and four at the Sub-district level.

\section{RESULT AND DISCUSSION}

From research at the Investment Management Unit and One-Stop Integrated Services (UP PM-PTSP) North Jakarta Administrative City through interviews with Key Informants and analysis of the Performance Plan Document (Renkin) and Performance Reports provide the following information:

In the implementation, policy implementors have understood their duties and functions but in the smooth running of the routine, there are still obstacles, namely lack of human resources, information technology equipment that is not up to date, and information technology experts only at the administrative city level of North Jakarta. Meanwhile, at the service level in district and sub-district, it is not available.

For electronic licensing services, according to Government Regulation Number 24 of 2018, OSS is a business license issued by the OSS Institute for and on behalf of ministers, institutional leaders, governors, or regents/mayors to business actors through an integrated electronic system.

On the other hand, the DKI government in April 2017 launched JakEVO, an application with the same function as OSS. In the policy, it is hoped that the two systems can be integrated.

The Coordinating Ministry for Economic Affairs stated that OSS in Jakarta has been connected to the existing licensing system in the PM-PTSP Service in DKI Jakarta, namely JakEVO, but in its implementation integration only occurs at sub-district level services based on the oral policy (unwritten policy) of the Head of PM-PTSP Service on January 15, 2020, namely the integration of JakEVO and OSS only in SIUP/ trading business licensing services. The other licenses are still being served in DKI Jakarta's standalone system. "The existence of two systems that have not been integrated, besides confusing the public, also makes public services inefficient.

The main problem with the OSS system is the incompatibility of central and regional regulations. The Guidelines for Norms, Standard Procedures, and Criteria (NSPK) which are technical guidelines for licensing services are not concrete in translating Government Regulation (PP) No.24 of 2018 concerning Electronic-Based Integrated Licensing Service Systems (OSS).

Apart from the NSPK, other OSS problems can also be seen from the incompatibility of PP 24/2018 with Law Number 25 of 2007 concerning Investment and Law Number 23 of 2014 concerning Regional Government. This disharmonis concerns the authority to grant permits, which previously was the authority of the regional head, now it has become the authority of the OSS institution

As a result, the function of the licensing agency that previously delegated the Investment Law to PTSP has now shifted to the OSS institution. 
Another problem in implementing OSS is that not all of the people receiving the SIUP licensing service understand how to use OSS. This is because not all people understand the internet. Even though there are posters of OSS instructions posted at the sub-district office or in the sub-district. PTSP officers have helped explain to the community, but the number of officers is limited.

At the central government level, the OSS system is also not fully integrated with the licensing system of Ministries and Agencies. In addition, the regions also have an application-based independent licensing system or One Stop Services (PTSP) which is not yet integrated with OSS. In fact, DKI Jakarta has only integrated JakEVO, the regional licensing system, and OSS only in the Trading Business License (SIUP) licensing service.

The main cause of this obstacle is because there has been no stipulation of service HR competency standards, which results in the online system service not being carried out according to the target, besides that there has not been any coordination in terms of the licensing process involving other agencies.

This happens because, from the aspect of staffing, it has not been assigned a functional position. So that it has not been provided with technical training in the field of public services. Furthermore, this results in services not running efficiently.

Reference to efficiency has been regulated in the Law on Public Services No. 25 of 2019, particularly as stated in articles 14 and 15 concerning the Rights and Obligations of Public Service Providers. On the other hand, it is further emphasized by De Leon's opinion in Hatty Suat (2014; 109) that in the implementation of public services, public administrators are clearly not only required to be able to work more professionally, efficiently, economically, and effectively, but also to be able to develop approaches. a more innovative approach to address new challenges that arise at the global level which, directly or indirectly, affect the work environment.

In assessing the quality of public services by the community, using the Servqual theory from Parasuraman et.al (1985: 41-50). It is said to have a fairly good level of responsiveness and empathy and the service has been running according to standard operating procedures (SOP).

Solutions are methods or ways used to solve or solve problems without any pressure. The purpose of pressure is the existence of objectivity in determining solutions where people who seek solutions do not impose their personal opinions and are guided by existing rules or regulations. (Munif Chatib: 2011) Choosing a solution is an action to solve a problem or a process that uses the power of thinking to align the problems at hand.

The solution to overcome various obstacles in implementing the PM-PTSP policy in North Jakarta has not yet been implemented. To overcome this, it is necessary to provide technical guidance to all implementers in stages from the city, district, and sub-district levels. It will be more effective if it is preceded by a transformation of the employment status from structural to functional. Another solution needs to be carried out more intensive socialization to the public about OSS procedures. 


\section{6 | Jurnal Ilmiah Ilmu Administrasi Publik: Jurnal Pemikiran dan Penelitian Administrasi Publik \\ Volume 10 Number 2, July-December 2020. Page 381-388}

\section{CONCLUSION}

1. In implementing the PM-PTSP policy in North Jakarta City, generally the implementer has understood its duties and functions, but in the smooth running of its duties, it is constrained by a lack of human resources both in quantity and quality, information technology equipment that is not up to date including the availability of information technology personnel at the district level and sub-district level.

2. The OSS policy according to Government Regulation Number 24 of 2018 has not been fully effective, because it has not been fully integrated with the existing licensing system in the PM-PTSP DKI Jakarta, namely JakEVO, and from the oral (unwritten) policy of the Head of the Service it is only implemented at the sub-district level.

3. The main obstacle to policy implementation, namely in terms of human resources, employee status has not been transferred to functional positions so that it affects career ranks and motivation. In addition, there is no set of HR competency standards for services, this results in the achievement of the performance plan (Renkin) for online system services not being carried out according to the target.

4. Solutions to overcome various obstacles have not been conceptually implemented, one of the practical operational technical steps is to provide technical guidance to employees, both at the city and sub-district and sub-district levels.

\section{REFERENCES}

A. Parasuraman, Leonard L. Berry, And Valarie A. Zeithaml. 1985. A Conceptual Model Of Services Quality And Its Implications For Future Research. Journal Of Marketing, Vol. 49, P. 41-50.

A. Parasuraman, Valarie A. Zeithaml, and Leonard L. Berry. 1988. "SERVQUAL: A MultipleItem Scale for Measuring Consumer Perceptions of Service Quality". Journal of Retailing. Vol 64 (1) pp 12-37

Ardianto, Elvinaro. 2014. Research Methodology for Quantitative and Qualitative Public Relations. Bandung: Simbiosa Rekatama Media

Creswell, John W. 2016. Research Design: Qualitative, Quantitative, and Mixed Approaches. Yogyakarta: Student Library

Chatib, Munif. 2011. Human Teacher: Making All Children Special and All Children Champions. Bandung: Mizan Pustaka

Oates, W.E., 1995. "Comment on Conflict and Dilemmas of Decentralization by Rudolf Holmes". The world Bank Research Observer. Pp 351-353 
Mary Ismowati, Akhmad Hidayat Rahadian, Muhammad Ali Massyhury, \begin{tabular}{l|l} 
and Muhammad Rafi Suryadi; Implementation of One-Stop Services... 1387
\end{tabular}

Pollit, Chirstopher, Johnston Birchall, and Keith Putman, 1998, Decentralizing Public Sevice Management, London: MacMillan.

Https://ekonomi.bisnis.com/read/20190926/9/1152731/pemda-masih-anggap-oss-melanggarotonomi -area

Hatty Suat (Populis, Volume 8 No. 2 October 2014; p. 109)

Regulations:

The Republic of Indonesia. Law of the Republic of Indonesia Number 25 of 2009 concerning Public Services.

The Republic of Indonesia. Law of the Republic of Indonesia Number 25 of 2007 concerning Investment

The Republic of Indonesia. Law of the Republic of Indonesia Number 23 of 2014 concerning Regional Government

Presidential Regulation No. 91 of 2017 concerning the acceleration of ease of doing business through the implementation of an information technology-based licensing system or Online Single Submission (OSS).

PP 24 of 2018 concerning Electronically Integrated Business Licensing Services (OSS)

Minister of Home Affairs Regulation No. 4 of 2010 stipulated integrated administrative service guidelines, hereinafter known as One-Stop Services (PTSP). 
388 | Jurnal Ilmiah Ilmu Administrasi Publik: Jurnal Pemikiran dan Penelitian Administrasi Publik

Volume 1o Number 2, July-December 2020. Page 381-388 